\title{
Mice Lacking Brain-Derived Neurotrophic Factor Exhibit Visceral Sensory Neuron Losses Distinct from Mice Lacking NT4 and Display a Severe Developmental Deficit in Control of Breathing
}

\author{
Jeffery T. Erickson, ${ }^{1}$ Joanne C. Conover, ${ }^{2}$ Veronique Borday, ${ }^{3}$ Jean Champagnat, ${ }^{3}$ Mariano Barbacid, ${ }^{4}$ \\ George Yancopoulos, ${ }^{2}$ and David M. Katz ${ }^{1}$ \\ ${ }_{1}^{1}$ Department of Neurosciences, Case Western Reserve University School of Medicine, Cleveland, Ohio 44106, \\ ${ }^{2}$ Regeneron Pharmaceuticals, Tarrytown, New York 10591, 3/nstitut Alfred Fessard, 91198 Gif-Sur-Yvette Cedex, France, \\ and ${ }^{4}$ Bristol-Myers Squibb, Princeton, New Jersey 08543
}

The neurotrophins brain-derived neurotrophic factor (BDNF) and neurotrophin-4/5 (NT4) act via the TrkB receptor and support survival of primary somatic and visceral sensory neurons. The major visceral sensory population, the nodose-petrosal ganglion complex (NPG), requires BDNF and NT4 for survival of a full complement of neurons, providing a unique opportunity to compare gene dosage effects between the two TrkB ligands and to explore the possibility that one ligand can compensate for loss of the other. Analysis of newborn transgenic mice lacking BDNF or NT4, or BDNF and NT4, revealed that survival of many NPG afferents is proportional to the number of functional BDNF alleles, whereas only one functional NT4 allele is required to support survival of all NT4-dependent neurons. In addition, subpopulation analysis revealed that BDNF and NT4 can compensate for the loss of the other to support a subset of dopaminergic ganglion cells. Together, these data demonstrate that the pattern of neuronal dependencies on BDNF and NT4 in vivo is far more heterogeneous than predicted from previous studies in culture. Moreover, BDNF knockout animals lack a subset of afferents involved in ventilatory control and exhibit severe respiratory abnormalities characterized by depressed and irregular breathing and reduced chemosensory drive. BDNF is therefore required for expression of normal respiratory behavior in newborn animals.

Key words: chemoreceptor; neurotrophin; nodose; petrosal; respiration; Sudden Infant Death Syndrome
The neurotrophins comprise a multigene family that includes nerve growth factor (NGF), brain-derived neurotrophic factor (BDNF), neurotrophin-3 (NT3), neurotrophin-4/5 (NT4), and neurotrophin-6 (NT6) (Davies, 1994; Snider, 1994; Lewin and Barde, 1996). These factors signal through the Trk family of protein tyrosine kinases; NGF acts primarily via TrkA, BDNF and NT4 via TrkB, and NT3 via TrkC, although all bind with equal affinity to the low-affinity neurotrophin receptor $\mathrm{p} 75^{\mathrm{LNR}}$ (for review, see Barbacid, 1994).

The fact that BDNF and NT4 both bind to TrkB with high affinity raises the question of whether these two ligands serve distinct or redundant functions in vivo. The two TrkB ligands seem indistinguishable in their ability to support survival of primary sensory neurons in culture (Davies et al., 1993; Ibáñez et al., 1993; Hertzberg et al., 1994), yet they seem capable of eliciting differential effects on survival and morphological development of

\footnotetext{
Received April 25, 1996; revised June 6, 1996; accepted June 12, 1996.

This work was supported by HL-24131 to D.M.K. and the Francis Families Foundation-Parker B. Francis Fellowship in Pulmonary Research to J.T.E. We gratefully acknowledge the assistance of Dr. Richard Smeyne (formerly of BristolMyers Squibb; currently at Hoffman-LaRoche) in obtaining TrkB knockout mice. We would also like to acknowledge the thoughtful comments of Drs. Lynn Landmesser and Tom Large. We thank Hua Jun He and Li Pan for expert technical assistance, Teresa Brosenitsch for quantitation of the in vitro studies, and Emily Buck and Charles Kunos for assistance with morphometric analyses.

Correspondence should be addressed to Dr. David M. Katz, Department of Neurosciences, Case Western Reserve University School of Medicine, 10900 Euclid Avenue, Cleveland, $\mathrm{OH} 44106$.

Dr. Conover's present address: Rockefeller University, 1230 York Avenue, New York, NY 10021.

Copyright (C) 1996 Society for Neuroscience $0270-6474 / 96 / 165361-11 \$ 05.00 / 0$
}

some CNS neurons (Cohen-Cory and Fraser, 1995; McAllister et al., 1995; Riddle et al., 1995).

We recently demonstrated that cells in the nodose-petrosal ganglion complex (NPG), the principal visceral sensory population, require both BDNF and NT4 for survival of a full complement of neurons (Conover et al., 1995; Liu et al., 1995). Analysis of cell loss in the NPG complex as a whole demonstrated additivity of the BDNF and NT4 null mutations, suggesting that the two TrkB ligands support primarily separate populations of ganglion cells (Conover et al., 1995; Liu et al., 1995). However, these studies did not examine survival of identified NPG neurons and therefore could not exclude the possibility that some of the same cells were affected by loss of both ligands. If this were true, it could indicate that BDNF and NT4 can compensate for each other to support survival of some TrkB neurons in vivo, as in vitro. In the present study, therefore, we examined similarities and differences in the biological activities of endogenous BDNF and NT4 by comparing survival requirements of an identified subpopulation of NPG neurons, distinguished by expression of dopaminergic (DA) phenotypic traits, as well as total neuron survival, in mice lacking functional BDNF, NT4, BDNF and NT4, or TrkB alleles. Survival of dopaminergic NPG neurons in culture is supported by both BDNF and NT4 but not other neurotrophins (Hertzberg et al., 1994). By analyzing both hetero- and homozygous animals, we also were able to examine potential gene dosage effects on NPG neuron survival. Although gene dosing has been reported for neuronal populations supported by BDNF, NGF, and NT3 (Crowley et al., 1994; Ernfors et al., 1994b, 1995; Bianchi et al., 1996), it is not known whether survival of NT4-dependent neurons is regulated similarly. 
The fact that the BDNF and TrkB null mutations are lethal, whereas animals lacking NT4 are viable (Klein et al., 1993; Ernfors et al., 1994a; Jones et al., 1994; Conover et al., 1995; Liu et al., 1995), argues for distinct physiological roles for the two TrkB ligands in vivo. Previously, we suggested that the lethality of the BDNF and TrkB mutations may be related specifically to loss of NPG neurons (Hertzberg et al., 1994; Conover et al., 1995). These cells provide sensory innervation to visceral tissues and thereby mediate cardiovascular, respiratory, and gastrointestinal reflexes critical for homeostasis. In particular, we proposed that loss of dopaminergic NPG neurons, associated with afferent pathways controlling respiration, could result in potentially lethal respiratory disturbances (Hertzberg et al., 1994). To examine this possibility, the present study characterized development of respiratory reflexes in BDNF-deficient mice by using whole-body plethysmography. These experiments demonstrated that loss of BDNF results in a severe developmental deficit in reflex control of respiration.

\section{MATERIALS AND METHODS}

\section{Cell culture}

Pregnant dams (Sprague Dawley strain, Zivic-Miller, Zelienople, PA) were killed by exposure to carbon dioxide. The uterine horns were removed and placed into PBS containing $10 \%$ glucose, and the embryos were excised. To assign gestational ages, the day after mating was designated Embryonic Day (E) 0.5. Fetal (E16.5) nodose ganglia were isolated and digested enzymatically in Dispase (Collaborative Research, Bedford, MA; diluted 1:1 in PBS) for $1 \mathrm{hr}$ at $37^{\circ} \mathrm{C}$, followed by trituration through fire-polished Pasteur pipettes. Cells were plated (one ganglion per well) onto glass coverslips coated with polylysine $(0.1 \mathrm{mg} / \mathrm{ml})$ and laminin $(0.3$ $\mathrm{g} / \mathrm{ml}$ ) and grown for 3-5 d in Leibovitz's L- $15 / \mathrm{CO}_{2}$ medium containing $10 \%$ NuSerum (Collaborative Research), 5\% heat-inactivated rat serum, fresh vitamin mixture (Mains and Patterson, 1973), penicillin (50 IU/ml), and streptomycin $(50 \mu \mathrm{g} / \mathrm{ml})$. Cultures were grown in the absence or presence of either BDNF alone $(10 \mathrm{ng} / \mathrm{ml})$, NT4 alone $(10 \mathrm{ng} / \mathrm{ml})$, or both BDNF and NT4 (10 ng/ml each). Cultures subsequently were fixed in $4 \%$ paraformaldehyde (in $0.1 \mathrm{~m}$ sodium phosphate buffer, $\mathrm{pH}$ 7.4) overnight at $4^{\circ} \mathrm{C}$ and processed for immunocytochemical staining as described below.

\section{Immunocytochemistry}

Cell cultures. Double-immunostaining was performed as follows with polyclonal anti-tyrosine hydroxylase (TH; 1:200; Pel-Freez, Rogers, AR), monoclonal anti-neurofilament protein $\left(\mathrm{NF}_{200,160,68} 1: 100\right.$; Sigma, St. Louis, MO), goat anti-rabbit IgG-FITC (1:200; Boehringer Mannheim, Indianapolis, IN), and goat anti-mouse IgG-Rhodamine (1:200; Cappel Research Products, Organon Teknika, Durham, NC): Cells were (1) incubated overnight at room temperature in anti-TH and anti-NF, diluted in PBS containing $0.5 \%$ Triton X-100; (2) washed three times in PBS; (3) incubated for $1 \mathrm{hr}$ at room temperature in goat anti-rabbit IgG-FITC plus goat anti-mouse IgG-Rhodamine diluted in PBS-Triton containing 10\% goat serum and $10 \%$ rat serum; (4) washed in PBS; (5) incubated in $\rho$-phenylenediamine $(1 \mathrm{mg} / \mathrm{ml})$ for $1 \mathrm{~min}$; (6) washed in PBS; and (7) coverslipped with glycerol gel.

Intact ganglia. Newborn animals were anesthetized deeply and perfused through the heart with $4 \%$ paraformaldehyde in $0.1 \mathrm{M}$ sodium phosphate buffer, $\mathrm{pH}$ 7.4. The head of the animal was hemisected along the midline, infiltrated with $30 \%$ sucrose for $24-48 \mathrm{hr}$, placed in a $1: 1$ mixture of $30 \%$ sucrose and Tissue Tek embedding medium (Baxter Scientific, McGraw Park, IL) for $24 \mathrm{hr}$, embedded and frozen in Tissue Tek, and stored at $-80^{\circ} \mathrm{C}$ until use. Frozen sections were cut $(10 \mu \mathrm{m})$, thaw-mounted onto gelatin-coated microscope slides, and then processed immunohistochemically as described above.

\section{Cell counts}

Dissociate cell cultures. The number of $\mathrm{TH}^{+}$and $\mathrm{NF}^{+}$neurons was counted in $\sim 10 \%$ of the area of each dissociate culture. Data were derived from three cultures per condition (control, +BDNF, +NT4, + BDNF and NT4) from three separate experiments and analyzed by ANOVA $(\alpha=0.05)$, followed by Tukey's multiple comparison procedure (Kleinbaum and Kupper, 1978).
Transgenic mice. BDNF-, NT4-, and BDNF/NT4-deficient mice (Conover et al., 1995) were obtained from Regeneron Pharmaceuticals, and TrkB-deficient animals (Klein et al., 1993) were provided by BristolMyers Squibb. Total cell counts: Mice were perfused transcardially with 4\% paraformaldehyde, and hemisected heads were paraffin-embedded, sectioned $(7 \mu \mathrm{m})$ in the sagittal plane, and stained with hematoxylin and eosin. All sections containing the NPG were identified, and every second or third section was analyzed to determine the volume of the complex occupied by neurons, using image analysis software (National Institutes of Health Image, v.1.55). Volumes $\left(\mu \mathrm{m}^{3} \times 10^{6}\right)$ were calculated from the cross-sectional area of measured sections occupied by neurons, section thickness, and the total number of NPG sections. Total neuron number for each NPG was estimated by sampling $\sim 20 \%$ of the sections; all sections from the beginning to the end of the NPG were parcellated into groups containing $4-5$ serial sections. Then one section from each group was selected randomly for analysis. The number of neuronal nuclei within a measured area of the section was counted, the neuronal density [number of neurons/(measured area $\times$ section thickness)] was calculated, and the mean of these measurements was multiplied by the volume of the NPG occupied by neurons. Corrected total counts were obtained from each animal by using the mean nuclear diameter derived from 75 individual measurements (Abercrombie, 1946). $\mathrm{TH}^{+}$profile counts: All TH-immunostained neuronal profiles with a nucleus in the plane of section were counted in every other section from each ganglion. No correction factor was applied. Total neuron and $\mathrm{TH}^{+}$profile counts from transgenic animals were analyzed by ANOVA $(\alpha=0.05)$, followed by Scheffé's multiple comparison procedure (Kleinbaum and Kupper, 1978).

\section{Plethysmography}

Resting ventilation in normoxia $\left(21 \% \mathrm{O}_{2}\right)$ and ventilatory responses to hyperoxia $\left(100 \% \mathrm{O}_{2}\right)$ and hypercapnia $\left(5 \% \mathrm{CO}_{2}\right)$ were measured in $b d n f^{+/+}$and $b d n f^{-/-}$mice, using a whole-body plethysmograph (Bartlett and Tenney, 1970) adapted for use with neonatal animals (Schweitzer et al., 1990). Individual, unanesthetized animals were placed in a chamber $(20 \mathrm{ml}$ of vol) that was connected to one side of a differential pressure transducer (model DP103-14, Validyne Engineering, Northridge, CA). Pressure changes were measured with reference to a second chamber of identical volume connected to the other side of the transducer. Temperature inside the chamber was measured with a thermocouple thermometer and maintained constant $\left(\right.$ mean $\left.\pm \mathrm{SE}=31.1 \pm 0.25^{\circ} \mathrm{C}\right)$. Each chamber communicated with atmospheric pressure through a slow leak (27 gauge hypodermic needle) to minimize pressure differences between the chambers because of fluctuations in atmospheric pressure during measurements. The analog signal from the transducer was demodulated

Table 1. Counts of total neurons in the NPG from postnatal day 1 mice with different combinations of functional and disrupted BDNF, NT4, and TrkB alleles

\begin{tabular}{lllc} 
& $\begin{array}{l}\text { Genotype } \\
(b d n f / n t 4 / \text { trkb })\end{array}$ & $\begin{array}{l}\text { Total neuron } \\
\text { number }(n)\end{array}$ & $\begin{array}{l}\text { Change } \\
(\%)\end{array}$ \\
\hline A & $(+/+) /(+/+) /(+/+)$ & $5654 \pm 384(6)$ & 0 \\
B & $(+/-) /(+/+) /(+/+)$ & $4402 \pm 212(4)^{a, b}$ & -22 \\
C & $(-/-) /(+/+) /(+/+)$ & $2974 \pm 141(6)^{a}$ & -47 \\
D & $(+/+) /(+/-) /(+/+)$ & $5175 \pm 663(4)^{c, e}$ & -8 \\
E & $(+/+) /(-/-) /(+/+)$ & $2799 \pm 417(5)^{a}$ & -50 \\
F & $(-/-) /(+/-) /(+/+)$ & $2571 \pm 778(2)^{d, f}$ & -54 \\
G & $(+/-) /(-/-) /(+/+)$ & $1499 \pm 112(5)^{c}$ & -73 \\
H & $(-/-) /(-/-) /(+/+)$ & $560 \pm 77(4)^{b, c}$ & -90 \\
I & $(+/+) /(+/+) /(-/-)$ & $326 \pm 71(3)^{g}$ & -94
\end{tabular}

Corrected cell counts are shown as means \pm SE. Percent change is compared to wild-type $\left(b d n f^{+/+} n t 4^{+/+} t r k b^{+/+}\right)$.

${ }^{a}$ Differs from $b d n f^{+/+} n t 4^{+/+} t r k b^{+/+}$(wild-type).

${ }^{b}$ Differs from $b d n f^{-/-} n t 4^{+/+} t r k b^{+/+}$(BDNF knockout).

${ }^{c}$ Differs from $b d n f^{+/+} n t 4^{-/-} t r k b^{+/+}$(NT4 knockout).

${ }^{d}$ Differs from $b d n f^{-/-} n t 4^{-/-}$trkb ${ }^{+/+}$(BDNF/NT4 double knockout).

${ }^{e}$ Not different from $b d n f^{+/+} n t 4^{+/+} t r k b^{+/+}$(wild-type).

${ }^{f}$ Not different from $b d n f^{-/-} n t 4^{+/+} t r k b^{+/+}$(BDNF knockout).

${ }^{g}$ Not different from $b d n f^{-/-} n t 4^{-/-} t r k b^{+/+}$(BDNF/NT4 double knockout); comparison using Student's $t$ test, $\alpha=0.05$. 

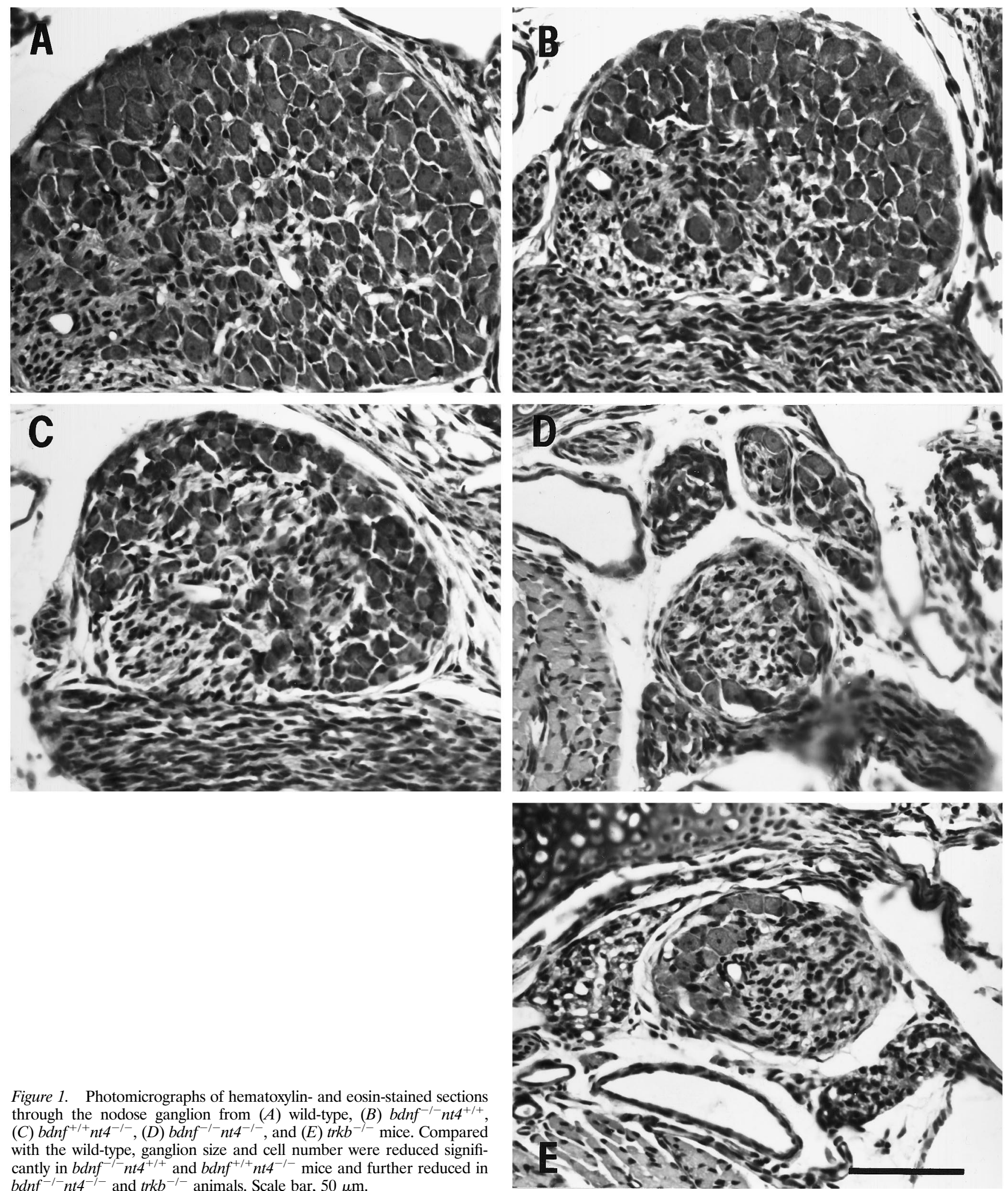

Figure 1. Photomicrographs of hematoxylin- and eosin-stained sections through the nodose ganglion from $(A)$ wild-type, $(B) b d n f^{-/-} n t 4^{+/+}$ (C) $b d n f^{+/+} n t 4^{-/-},(D) b d n f^{-/-} n t 4^{-/-}$, and $(E) t r k b^{-/-}$mice. Compared with the wild-type, ganglion size and cell number were reduced significantly in $b d n f^{-/-} n t 4^{+/+}$and $b d n f^{+/+} n t 4^{-/-}$mice and further reduced in $b d n f^{-1-} n t 4^{-1-}$ and $t r k b^{-1-}$ animals. Scale bar, $50 \mu \mathrm{m}$.

(model CD-15 carrier demodulator, Validyne Engineering), amplified, filtered, passed through an analog-to-digital converter (Labmaster TL-1), and then captured and stored to disk by computer (pClamp, v.5.5.1, Axon Instruments, Foster City, CA). Signals were calibrated by recording pressure changes associated with known volumes of air injected into the chambers through a microliter syringe. Barometric pressure was obtained before each recording session.
The baseline ventilatory pattern in normoxia was recorded from each animal for 2-3 min before the presentation of each test gas. Then the animal was exposed to the test gas for $2 \mathrm{~min}$, and a continuous recording of ventilation was obtained for an additional 2-3 min period. Baseline ventilatory measurements were made on postnatal days 2.5 and 4.5 . Responses to hyperoxia were obtained on postnatal day 2.5 , whereas responses to elevated $\mathrm{CO}_{2}$ levels were obtained on postnatal day 3.5. The 
hypercapnic gas mixture was obtained by mixing pure $\mathrm{CO}_{2}$ with room air. The composition of the warmed and humidified gas mixtures was measured with gas analyzers (models $\mathrm{OM}-11 \mathrm{O}_{2}$ and $\mathrm{LB}-2 \mathrm{CO}_{2}$ analyzers, Beckman Instruments, Fullerton, CA) calibrated with gases of precisely known $\mathrm{O}_{2}$ or $\mathrm{CO}_{2}$ content. Data were analyzed by paired $t$ tests or ANOVA $(\alpha=0.05)$, followed by Scheffé's multiple comparison procedure (Kleinbaum and Kupper, 1978).

\section{RESULTS}

Analysis of total neuron survival revealed that both BDNF and NT4 were required for survival of a full complement of NPG neurons in newborn transgenic mice, consistent with previous observations in fetal and 2-week-old animals (Conover et al., 1995; Liu et al., 1995). Loss of either BDNF or NT4 alone reduced the total number of NPG neurons by $\sim 50 \%$ (Table 1C,E; Fig. $1 B, C)$; the sum of the reductions observed in mice lacking either BDNF or NT4 individually $(97 \%)$ was similar to the reduction observed after disruption of both neurotrophin genes simultaneously $(90 \%$; Table $1 \mathrm{H})$ or after loss of TrkB (94\%; Table $1 \mathrm{I})$. Thus, for the majority of newborn NPG neurons, endogenous BDNF and NT4 act in a primarily noncompensatory and nonredundant manner and target predominantly separate subpopulations of ganglion cells in vivo.

\section{Subpopulation analysis reveals compensation between BDNF and NT4}

Although the pattern of total neuron survival in BDNF and NT4 knockout mice suggested these factors support predominantly separate populations of ganglion cells, we could not rule out the possibility that small subsets of ganglion cells were, in fact, targeted by both ligands. To explore this possibility, we examined survival of a subpopulation of ganglion cells distinguished by their expression DA transmitter traits. These cells, which comprise $\sim 15-20 \%$ of all NPG neurons, can be distinguished from other ganglion neurons by expression of the catecholamine-synthesizing enzyme tyrosine hydroxylase (TH). Loss of both BDNF alleles led to a $58 \%$ reduction in the number of $\mathrm{TH}$-immunoreactive $\left(\mathrm{TH}^{+}\right)$ neurons in the NPG (Table $2 \mathrm{C}$; compare Fig. $2 A, C$ ), similar to the reduction in total neuron survival, indicating that a subset of DA neurons depend exclusively on BDNF. In contrast, there was no significant change in the number of $\mathrm{TH}^{+}$neurons in the absence of both NT4 alleles (Table 2E; Fig. 2B), indicating that these cells do not require NT4 for survival. The intensity of TH immunoreactivity was comparable in ganglia from wild-type, BDNF, and NT4 knockout animals (compare Fig. $2 A-C$ ). The fact that both the number of $\mathrm{TH}^{+}$neurons and total NPG cell counts decreased by approximately the same amount in $b d n f^{-/-} n t 4^{+/+}$animals indicates that the loss of $\mathrm{TH}^{+}$neurons was caused by decreased survival rather than by diminished $\mathrm{TH}$ expression.

Although TH cell counts were unchanged in $b d n f^{+/+} n t 4^{-/-}$ mice compared with wild-type controls, loss of BDNF plus NT4 led to a $25 \%$ greater reduction in $\mathrm{TH}$ cell number than loss of BDNF alone. These data indicate that, in the absence of BDNF, a substantial subset of DA neurons can be supported by NT4 (compare Table 2C,F,H). Therefore, BDNF and NT4 can compensate for the loss of the other to promote survival of at least this subset of ganglion cells. These data contrast sharply with the results of in vitro experiments indicating that BDNF and NT4 support the same populations of nodose and other sensory neurons in culture (Fig. 3; Davies et al., 1993; Ibáñez et al., 1993).
Table 2. Counts of $\mathrm{TH}^{+}$neuronal profiles in the NPG from postnatal day 1 mice with different combinations of functional and disrupted BDNF, NT4, and TrkB alleles

\begin{tabular}{lllc} 
& $\begin{array}{l}\text { Genotype } \\
(\text { bdnf/nt4/trkb })\end{array}$ & $\begin{array}{l}\mathrm{TH}^{+} \text {profile } \\
\text { number }(n)\end{array}$ & $\begin{array}{l}\text { Change } \\
(\%)\end{array}$ \\
\hline $\mathrm{A}$ & $(+/+) /(+/+) /(+/+)$ & $393 \pm 18(6)$ & 0 \\
$\mathrm{~B}$ & $(+/-) /(+/+) /(+/+)$ & $266 \pm 17(6)^{a, b}$ & -32 \\
$\mathrm{C}$ & $(-/-) /(+/+) /(+/+)$ & $165 \pm 11(6)^{a}$ & -58 \\
$\mathrm{D}$ & $(+/+) /(+/-) /(+/+)$ & $448 \pm 22(6)^{e, g}$ & +14 \\
$\mathrm{E}$ & $(+/+) /(-/-) /(+/+)$ & $353 \pm 40(5)^{e}$ & -10 \\
$\mathrm{~F}$ & $(-/-) /(+/-) /(+/+)$ & $169 \pm 32(3)^{f, d}$ & -57 \\
$\mathrm{G}$ & $(+/-) /(-/-) /(+/+)$ & $247 \pm 10(8)^{c, d}$ & -37 \\
$\mathrm{H}$ & $(-/-) /(-/-) /(+/+)$ & $66 \pm 2(4)^{b, c}$ & -83 \\
$\mathrm{I}$ & $(+/+) /(+/+) /(-/-)$ & $53 \pm 8(3)^{h}$ & -86
\end{tabular}

$\overline{\text { Profile counts are shown as means } \pm \text { SE. Percent change is compared with wild-type }}$ $\left(\right.$ bdnf $f^{+/+} n t 4^{+/+}$trkb $\left.{ }^{+/+}\right)$.

${ }^{a}$ Differs from $b d n f^{+/+} n t 4^{+/+} t r k b^{+/+}$(wild-type).

${ }^{b}$ Differs from $b d n f^{-/-} n t 4^{+/+} t r k b^{+/+}$(BDNF knockout).

${ }^{c}$ Differs from $b d n f^{+/+} n t 4^{-/-} t r k b^{+/+}$(NT4 knockout).

${ }^{d}$ Differs from $b d n f^{-/-} n t 4^{-/-} t r k b^{+/+}$(BDNF/NT4 double knockout).

${ }^{e}$ Not different from $b d n f^{+/+} n t 4^{+/+} t r k b^{+/+}$(wild-type).

${ }^{f}$ Not different from $b d n f^{-/-} n t 4^{+/+} t r k b^{+/+}$(BDNF knockout).

${ }^{g}$ Not different from $b d n f^{+/+} n t 4^{-/-} t r k b^{+/+}$(NT4 knockout).

${ }^{h}$ Not different from $b d n f^{-/-} n t 4^{-/-} t r k b^{+/+}$(BDNF/NT4 double knockout); comparison using Student's $t$ test, $\alpha=0.05$.

\section{Sensory neuron survival is proportional to the number of functional BDNF, but not NT4, alleles}

To compare gene dosage effects between BDNF and NT4, we analyzed neuron survival in heterozygous animals. Our data demonstrate that a large proportion of NPG neurons depends on the number of BDNF alleles in a dose-dependent manner. The percentage reduction in either total neuron number or the number of DA neurons in $b d n f^{+-}$mice was approximately half that observed in $b d n f^{-1-}$ animals (Tables $1 \mathrm{~A}-\mathrm{C}$ and E, G,H, 2A-C and $\mathrm{E}, \mathrm{G}, \mathrm{H})$, implying that these neurons normally are supported by limiting amounts of BDNF. In contrast, loss of one NT4 allele had no effect on total NPG neuron survival, either in the presence or absence of functional BDNF alleles; rather, survival of NT4dependent neurons was decreased only after disruption of both NT4 alleles (Table 1A,D,E and C,F,H). Similarly, a decrease in $\mathrm{TH}^{+}$neurons was observed only after loss of both NT4 alleles, in the absence of BDNF (compare Table 2C,F,H). These data indicate that a full complement of NT4-dependent neurons can be supported by a single functional NT4 allele, highlighting a fundamental difference between BDNF- and NT4-mediated survival in vivo.

\section{BDNF-deficient mice exhibit severe developmental deficits in respiratory control}

Our subpopulation analysis demonstrated that DA neurons in the NPG are severely depleted in $t r k b^{-/-}$and $b d n f^{-1-}$, but not in $n t 4^{-1-}$, mice. A large proportion of these cells innervate the carotid body (Katz et al., 1983; Katz and Black, 1986; Finley et al., 1992), a chemoreceptor organ that provides tonic excitatory drive to ventilation (Dejours, 1962) and the primary site at which hypoxemia triggers homeostatic cardiorespiratory reflexes (Heymans and Heymans, 1927; Heymans and Bouckaert, 1930). We therefore hypothesized that loss of these cells would result in abnormal breathing, possibly contributing to the lethality associated with loss of BDNF or TrkB.

To determine whether respiratory control was altered by loss of 

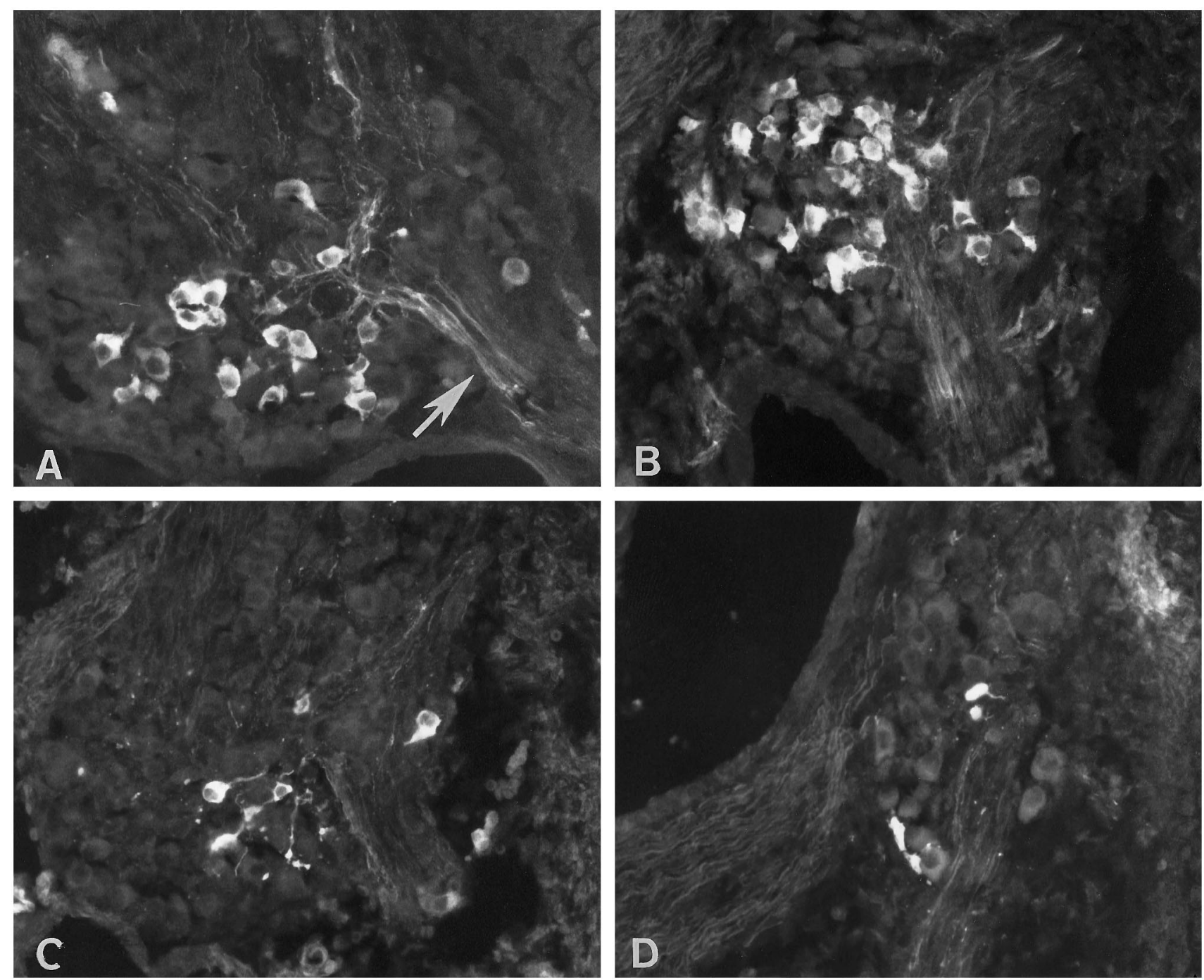

Figure 2. Photomicrographs of TH-immunostained sections through the petrosal ganglion, taken at the level of the glossopharyngeal nerve (arrow), from (A) wild-type, $(B) b d n f^{+/+} n t 4^{-/-},(C)$ $b d n f^{-1-} n t 4^{+/+},(D) b d n f^{-1-} n t 4^{-1-}$, and $(E) t r k b^{-1-}$ mice. Compared with the wild-type, the number of $\mathrm{TH}^{+}$profiles was reduced significantly in $b d n f^{-1-} n t 4^{+/+}, b d n f^{-/-} n t 4^{-/-}$, and $t r k b^{-/-}$mice but was unchanged in $b d n f^{+/+} n t 4^{-/-}$animals. Scale bar, $100 \mu \mathrm{m}$.

BDNF, we first compared resting ventilation in wild-type and BDNF-deficient mice with whole-body plethysmography. All animals exhibited irregularities in ventilation during the first $1-2 \mathrm{~d}$ of life, as is typical of newborn animals (Mortola, 1984); however, differences in breathing pattern between $b d n f^{+/+}$and $b d n f^{-/-}$ mice were apparent as early as 6-12 hr after birth (Fig. 4). By $2 \mathrm{~d}$

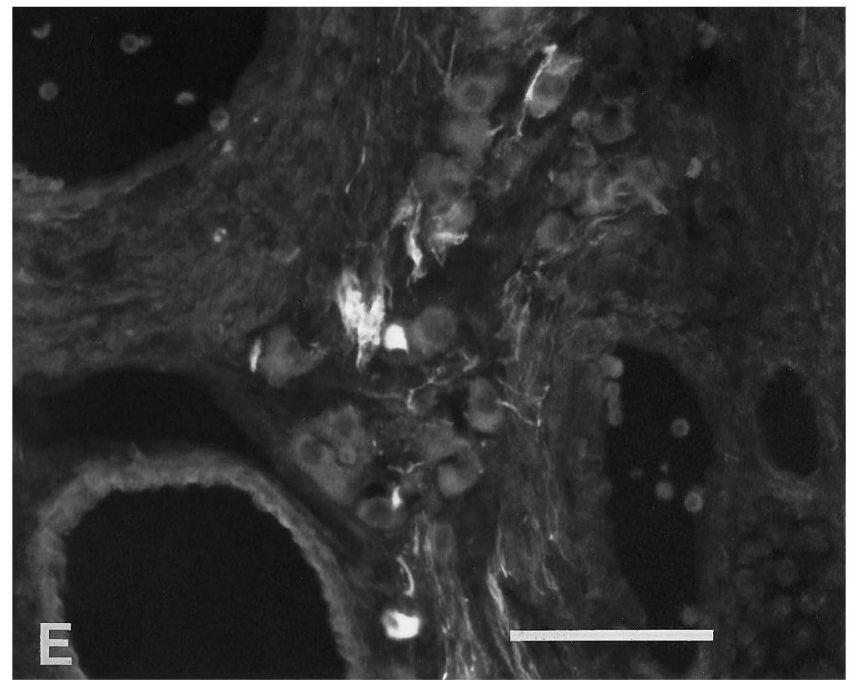

of age, when the respiratory rhythm in $b d n f^{+/+}$animals was well established and regular, the ventilatory pattern in $b d n f^{-/-}$animals remained irregular, with end-expiratory pauses and occasional apneas ( $>2-3 \mathrm{sec}$ intervals between breaths). Quantitative analysis at this age revealed that tidal volume $\left(V_{\mathrm{T}} ;\right.$ a measure of the amount of air moving in and out of the lungs) and breathing 


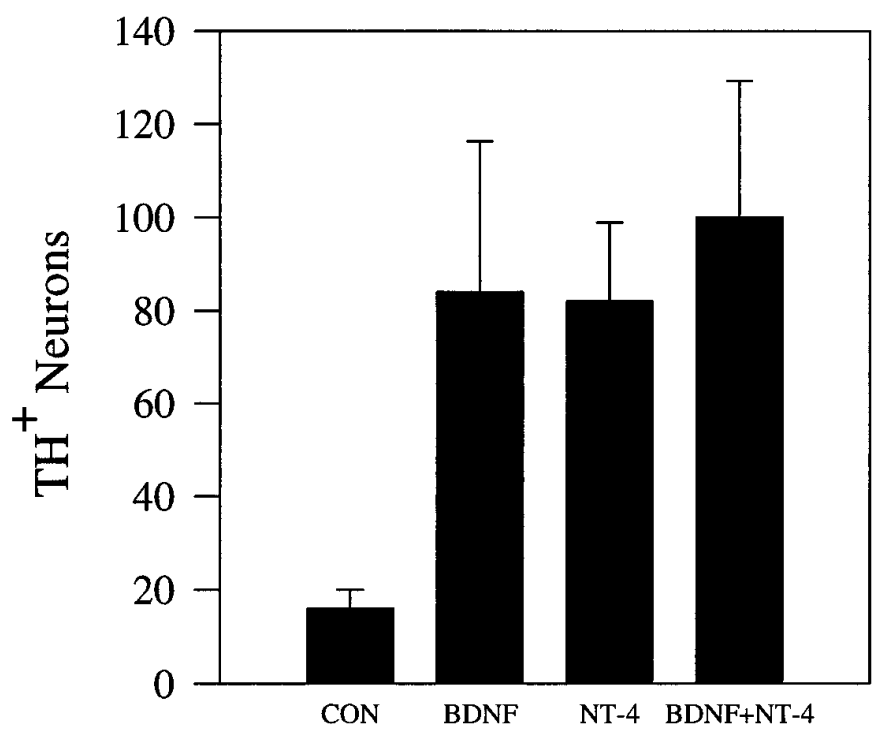

Figure 3. BDNF and NT4 support survival of DA nodose neurons to the same degree in vitro. Values are means \pm SEM of cell counts from three separate experiments with three cultures per condition per experiment. The presence of BDNF and NT4 together does not increase $\mathrm{TH}^{+}$neuron number, as compared with cultures supplemented with either neurotrophin alone. Moreover, total neuronal survival was similar in the presence of BDNF, NT4, or BDNF plus NT4 (BDNF alone, $3570 \pm 268$; NT4 alone, $3525 \pm 300$; BDNF plus NT4, $3628 \pm 181$ neurons, respectively).

frequency $(f)$ in $b d n f^{-1-}$ mice were reduced by 43 and $49 \%$, respectively, compared with $b d n f^{+/+}$animals (Table $3 \mathrm{~A}$ ), resulting in a $70 \%$ decrease in minute ventilation $\left(\dot{V}_{\mathrm{E}}=V_{\mathrm{T}} \times f\right)$. Two days later, on postnatal day $4.5, \dot{V}_{\mathrm{E}}$ was still $52 \%$ below the wild-type control value (Table $3 \mathrm{~A}$ ), demonstrating that the ventilatory depression in $b d n f^{-1-}$ animals was not a transient phenomenon associated with initial adjustments to postnatal life. A cycleby-cycle analysis of the breathing pattern at this age demonstrated a twofold increase in variability of $V_{\mathrm{T}}$ and $f$ in $b d n f^{-1-}$ animals (Table 4). Thus, disruption of both $b d n f$ alleles resulted in a drastic reduction in resting ventilation and highly irregular breathing.

Input from the peripheral chemoreceptors provides a tonic excitatory drive to breathing, allowing continuous reflex adjustments to changes in arterial oxygen tension (Dejours, 1962). We hypothesized, therefore, that loss of this input might account for the reduced and irregular ventilation of $b d n f^{-1-}$ mice. To assess whether oxygen-sensing mechanisms were altered in BDNFdeficient mice, we measured resting ventilation in $b d n f^{+/+}$and $b d n f^{-1-}$ animals before and during a short exposure to $100 \% \mathrm{O}_{2}$ (hyperoxia). In normal newborn rodents, hyperoxia depresses ventilation, presumably by decreasing activity in the peripheral chemoreceptors (Hertzberg et al., 1990). Moreover, the magnitude of the hyperoxia-induced ventilatory depression provides a measure of chemoafferent drive (Dejours, 1962; Hertzberg et al., 1990). As expected, hyperoxia decreased $\dot{V}_{\mathrm{E}}$ on postnatal day 2.5 in $b d n f^{+/+}$mice by $30 \%$ during periods of quiet uninterrupted breathing, indicating the presence of a significant chemoafferent drive to ventilation in normal animals. In contrast, $100 \% \mathrm{O}_{2}$ produced no significant decrease in $\dot{V}_{\mathrm{E}}$ in $b d n f^{-/-}$mice during quiet breathing (Fig. $5 A$; Table $3 \mathrm{~B}$ ), consistent with a loss of hypoxic drive in these animals. However, $b d n f^{-/-}$mice did exhibit increased incidence of apneas during hyperoxia, as compared with wild-type animals.
To examine whether $b d n f^{-/-}$mice were simply refractory to all chemical inputs to ventilation, we also evaluated responsiveness to increased inspired $\mathrm{CO}_{2}$, a physiological stimulus that increases respiration by activating both peripheral and central chemoreceptors (Cherniack and Longobardo, 1981). Mild hypercapnia (5\% $\mathrm{CO}_{2}$ ) increased breathing frequency in $b d n f^{-/-}$mice by $59 \%$ (Fig. $5 B$; normoxia, $120 \pm 4$ vs hypercapnia, $191 \pm 10$ breaths $/ \mathrm{min} ; n=$ 5 ; $p<0.01$ ), demonstrating that the respiratory controller was responsive to increased $\mathrm{CO}_{2}$ and that BDNF-deficient mice were capable of increasing ventilation above normoxic resting levels.

\section{DISCUSSION}

The present study demonstrates a spectrum of neuronal dependencies on TrkB ligands in vivo that contrasts sharply with results obtained from in vitro assays of neuronal survival. Thus, we have shown that some NPG subpopulations depend exclusively on BDNF for survival and others depend on NT4, whereas yet others can be supported by either BDNF or NT4. The finding that BDNF and NT4 can substitute for the other in supporting survival of some neurons provides the first evidence of compensatory or redundant actions of endogenous TrkB ligands on neuronal survival. Moreover, our analysis of heterozygous animals has revealed a fundamental difference between BDNF- and NT4mediated survival of visceral sensory neurons in vivo. Finally, we have demonstrated that loss of BDNF results in depressed and irregular breathing and reduced chemosensory drive that correlates with a severe loss of chemoafferent neurons in the NPG.

The difference between in vitro survival responses to exogenous factors (Fig. 3) and in vivo responses to neurotrophin gene deletions (Tables 1,2$)$ was striking and may be related to the diversity of target tissues innervated by NPG neurons in situ. For example, subsets of ganglion cells may project to targets that provide either one or the other, or both, TrkB ligands. Indeed, BDNF and NT4 mRNAs have been detected in developing visceral tissues with overlapping, although not identical, spatial and temporal distributions (Timmusk et al., 1993). It is also possible, however, that neurotrophins could act selectively on subsets of NPG neurons in vivo by activating different TrkB isoforms, a selectivity that may be masked by saturating levels of growth factor in culture. At least eight different mRNA transcripts encoding at least three different TrkB isoforms have been identified in mammals (Klein et al., 1989, 1990; Middlemas et al., 1991), and additional isoforms have been demonstrated in the developing avian visual system (Garner et al., 1996). Moreover, recent studies have shown that BDNF and NT4 can mediate distinct biological effects on the same population of neurons. For example, BDNF and NT4 each promote distinct, lamina-specific patterns of dendritic growth in pyramidal neurons in developing ferret visual cortex (McAllister et al., 1995), and NT4, but not BDNF, prevents death of lateral geniculate neurons after monocular deprivation (Riddle et al., 1995). In addition, exogenous BDNF and NT4 produce distinctive axonal morphologies in developing retinal ganglion cell projections in Xenopus optic tectum (Cohen-Cory and Fraser, 1995). We cannot rule out the possibility, therefore, that activation of different TrkB isoforms, expressed selectively by subsets of NPG neurons, could account for the diversity of requirements for BDNF and NT4 exhibited by NPG neurons in vivo.

A prediction of the neurotrophic hypothesis is that growth factor concentration is limiting for neuron survival in vivo (LeviMontalcini, 1987). Mice heterozygous for the NGF gene display an intermediate responsiveness to pain (Crowley et al., 1994), and NT3 heterozygotes contain an intermediate number of muscle 


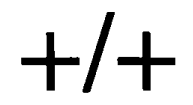

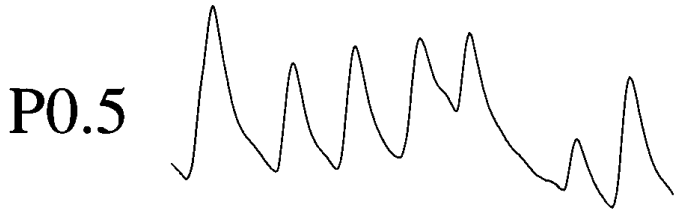


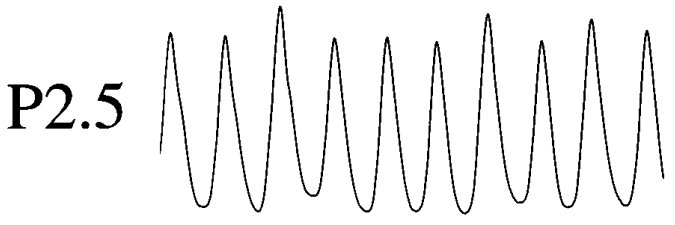
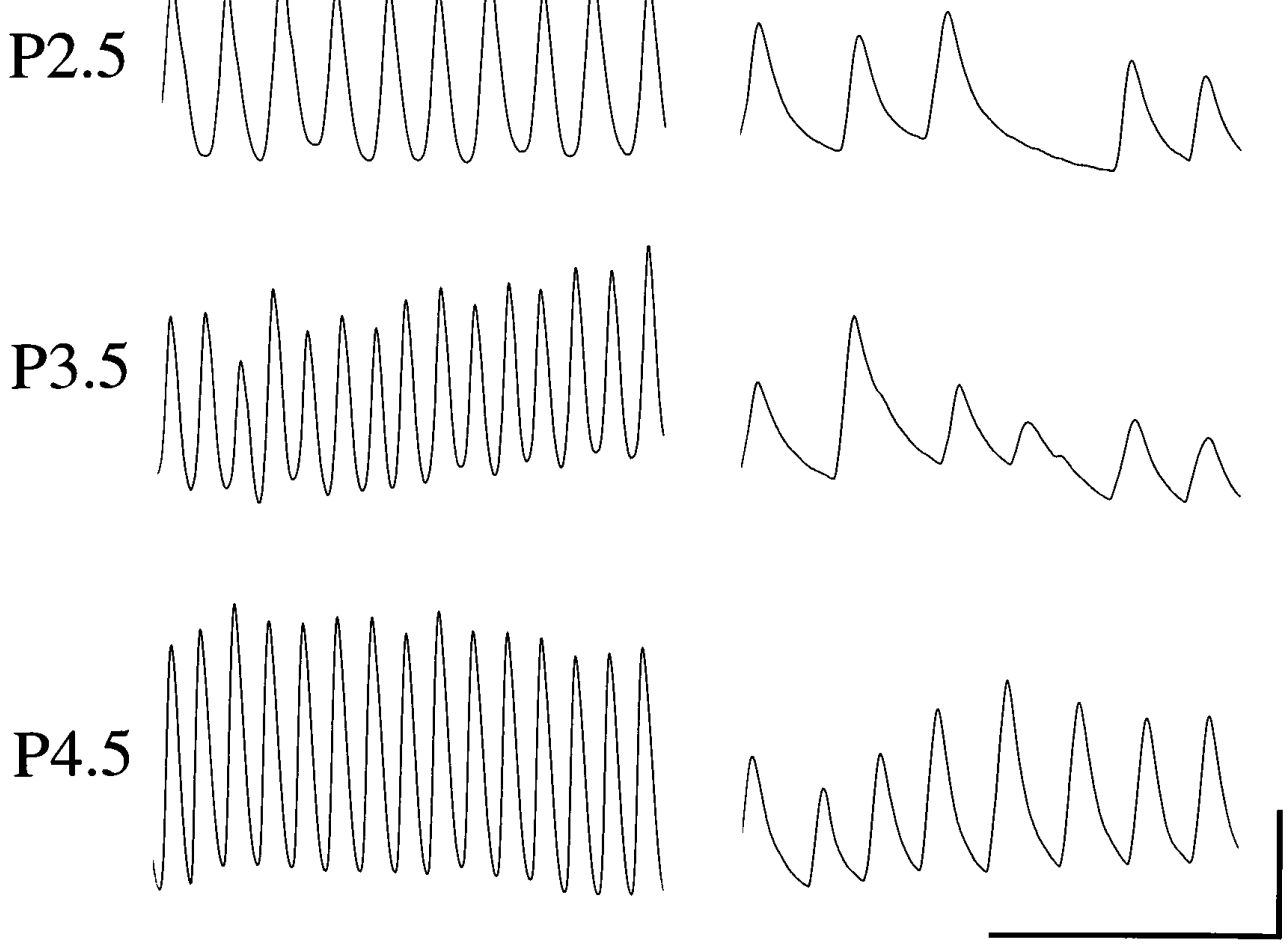

Figure 4. Plethysmograph records of resting ventilation in normoxia from individual $b d n f^{+/+}$and $b d n f^{-/-}$littermates during the first $4 \mathrm{~d}$ of postnatal life (P0.5P4.5). Differences in the pattern of resting ventilation between wild-type and knockout animals were apparent as early as $6-12 \mathrm{hr}$ after birth. Scale bars: vertical, $20 \mu \mathrm{l}$; horizontal, $2 \mathrm{sec}$.

spindles (Ernfors et al., 1994b), as compared with wild-type and homozygous mice. Moreover, approximately half as many neurons are lost in the vestibular ganglion of mice as compared with animals lacking both $b d n f$ alleles (Ernfors et al., 1995; Bianchi et al., 1996). These results suggest that the availability of NGF, NT3, and BDNF in vivo is limiting for survival of neurons dependent on these factors. We have demonstrated that approximately half of all NPG neurons depend on BDNF for survival in a dosedependent manner, implying that these neurons normally are supported by limiting amounts of BDNF. In contrast, the NT4dependent population of NPG neurons can be supported fully by a single, functional $n t 4$ allele. It is possible that NT4 availability in wild-type animals is not limiting for neuron survival. Alternatively, NT4 may be limiting, yet, in the absence of one allele, NT4 synthesis is up-regulated from the remaining allele to levels suf- ficient to support all NT4-dependent neurons. It is also possible that loss of one allele increases NT4 responsiveness in dependent neurons, perhaps via up-regulation of the low-affinity neurotrophin receptor $\mathrm{p} 75^{\mathrm{LNR}}$ or TrkB itself. The precise function of p $75^{\mathrm{LNR}}$ in neurotrophin signaling is not known (Chao, 1994; Chao and Hempstead, 1995). Although this receptor seems capable of Trk-independent signal transduction through the sphingomyelin pathway (Dobrowsky et al., 1994), p75 ${ }^{\text {LNR }}$ also may interact with Trk receptors to promote neurotrophin receptor discrimination (Benedetti et al., 1993; Clary and Reichardt, 1994), increase Trk responsiveness (Hantzopoulos et al., 1994), and participate in retrograde transport of neurotrophins (Johnson et al., 1987; von Bartheld et al., 1994; Curtis et al., 1995). Indeed, recent studies indicate that $\mathrm{p} 75^{\mathrm{LNR}}$ plays an important role in modulating biological responsiveness to NT4 (Curtis et al., 1995; Rydén et al., 
Table 3. Ventilatory measurements from wild-type $(+/+)$, bdnf heterozygotes (+/-), and bdnf homozygotes (-/-) during quiet uninterrupted breathing in room air (A) and during exposure to $100 \% \mathrm{O}_{2}(\mathrm{~B})$

\begin{tabular}{|c|c|c|c|c|c|}
\hline Genotype & $(n)$ & Age & $V_{\mathrm{T}}(\mu \mathrm{l} / \mathrm{g})$ & $f$ (breaths/min) & $\dot{V}_{\mathrm{E}}\left(\mathrm{ml} \cdot \mathrm{min}^{-1} \cdot \mathrm{gm}^{-1}\right)$ \\
\hline \multicolumn{6}{|c|}{ A. Normoxia } \\
\hline$+/+$ & 5 & $\mathrm{P} 2.5$ & $13.6 \pm 0.9$ & $209.2 \pm 9.4$ & $2.9 \pm 0.3$ \\
\hline$+1-$ & 9 & $\mathrm{P} 2.5$ & $11.5 \pm 0.5$ & $196.1 \pm 9.4$ & $2.3 \pm 0.2$ \\
\hline$-1-$ & 6 & $\mathrm{P} 2.5$ & $7.8 \pm 0.6^{a, b}$ & $107.3 \pm 8.1^{a, b}$ & $0.9 \pm 0.1^{a, b}$ \\
\hline$+/+$ & 10 & $\mathrm{P} 4.5$ & $14.3 \pm 1.1$ & $246.5 \pm 11.0$ & $3.5 \pm 0.3$ \\
\hline$+1-$ & 17 & $\mathrm{P} 4.5$ & $12.1 \pm 0.8$ & $249.1 \pm 6.1$ & $3.0 \pm 0.2$ \\
\hline$-1-$ & 6 & $\mathrm{P} 4.5$ & $10.3 \pm 1.1^{c}$ & $157.0 \pm 4.6^{a, b}$ & $1.6 \pm 0.2^{a, b}$ \\
\hline \multicolumn{6}{|c|}{ B. Hyperoxia } \\
\hline$+/+$ & 5 & $\mathrm{P} 2.5$ & $10.2 \pm 1.3^{d}$ & $194.4 \pm 14.4^{e}$ & $2.0 \pm 0.3^{d}$ \\
\hline$+1-$ & 9 & $\mathrm{P} 2.5$ & $8.6 \pm 0.6^{d}$ & $222.6 \pm 6.9^{d}$ & $1.9 \pm 0.2^{d}$ \\
\hline$-1-$ & 4 & $\mathrm{P} 2.5$ & $7.4 \pm 2.2$ & $109.2 \pm 17.1$ & $0.8 \pm 0.3$ \\
\hline
\end{tabular}

Values represent means $\pm \mathrm{SE}$.

${ }^{a}$ Differs from $+/+$.

${ }^{b}$ Differs from $+/-$

${ }^{c}$ Comparison of $+/+$ vs $-/-, p=0.0660$.

${ }^{d}$ Differs from normoxia.

${ }^{e} \mathrm{p}=0.0906$, compared with normoxia.

1995). Whether NT4 can regulate expression of $\mathrm{p} 75^{\mathrm{LNR}}$, however, remains to be defined.

Recent studies have indicated that the specificities of neurotrophin interactions with their preferred Trk receptors may not be absolute. In particular, NT3 has been shown to activate both TrkA and TrkB receptors in vitro, but the extent to which this occurs in vivo is not known (Cordon-Cardo et al., 1991; Klein et al., 1991; Soppet et al., 1991; Squinto et al., 1991; Ip et al., 1993). In the NPG, although neuron numbers are depleted by $\sim 90 \%$ in $b d n f^{-1-} n t 4^{-1-}$ mice (Table $1 \mathrm{H}$; Fig. $1 D$ ), BDNF and NT4 are not the only trophic factors that support survival of NPG neurons in vivo. NPG neurons (30-50\%) also are lost in mice lacking NT3 (Ernfors et al., 1994b; Fariñas et al., 1994), indicating that NT3 and TrkB ligands must act either sequentially (Buchman and Davies, 1993) or simultaneously to support survival of overlapping populations of NPG neurons. Davies et al. (1995) have provided evidence that NT3 may act via TrkB to support survival of nodose neurons in culture. However, the fact that neuronal losses are comparable in $b d n f^{-/-} n t 4^{-/-}$and $t r k b^{-/-}$mice (Tables $1 \mathrm{H}, \mathrm{I}$, $2 \mathrm{H}, \mathrm{I})$ indicates that few, if any, cells in this ganglion are supported exclusively by NT3 acting via the TrkB receptor in vivo.

NT4-deficient mice appear normal, are long-lived, and produce viable offspring, whereas BDNF and TrkB knockout mice die by 3 weeks of age (Klein et al., 1993; Ernfors et al., 1994a; Jones et al.,

Table 4. Coefficient of variation (SD/mean) derived from cycle-by-cycle measurements of tidal volume $\left(V_{\mathrm{T}}\right)$ and breathing frequency $(f)$ in P4.5 wild-type, heterozygous, and homozygous knockout mice

\begin{tabular}{lrll} 
Genotype & $(n)$ & $\begin{array}{l}\text { Coefficient of variation } \\
\left(V_{\mathrm{T}}\right)\end{array}$ & $\begin{array}{l}\text { Coefficient of variation } \\
(f)\end{array}$ \\
\hline$+/+$ & 10 & $22.7 \pm 5.0 \%$ & $19.4 \pm 2.4 \%$ \\
$+/-$ & 15 & $28.2 \pm 2.5 \%$ & $18.8 \pm 1.7 \%$ \\
$-/-$ & 6 & $48.6 \pm 5.0 \%^{a, b}$ & $37.3 \pm 3.9 \%$ \\
\hline
\end{tabular}

BDNF-deficient mice displayed a significant increase in cycle-to-cycle variability in both $V_{\mathrm{T}}$ and $f$ compared with wild-type and heterozygous animals. Values represent means \pm SE. Mean number of measured cycles per animal: $+/+368 ;+/-406 ;-/-$ 310 .

${ }^{a}$ Differs from $+/+$.

${ }^{b}$ Differs from $+/-$.
1994; Conover et al., 1995; Liu et al., 1995). Therefore, BDNFbut not NT4-dependent neurons seem to be critical for survival after birth. In the present study we show that $b d n f^{-/-}$mice display depressed and irregular resting ventilation from birth. Moreover, hypoxic chemosensory drive in these animals is reduced severely. These respiratory abnormalities correlate with a severe loss of DA neurons in the NPG, a large proportion of which are believed to transmit chemosensory information from the carotid body (Katz et al., 1983; Katz and Black, 1986; Finley et al., 1992). Because ventilation and metabolic rate also are influenced by body temperature, particularly in newborn animals, further studies will be required to evaluate potential contributions of these factors to the knockout respiratory phenotype. Taken together, however, our findings indicate that loss of chemosensory input could account for the reduced and irregular breathing of BDNF-deficient mice. Indeed, this idea is strengthened by the observation that surgical denervation of the peripheral chemoreceptors in newborn rats produces a highly irregular pattern of breathing, characterized by arrhythmic low amplitude breaths, frequent end-expiratory pauses, and apneas (Hofer, 1984, 1986) similar to that observed in BDNF knockout animals. Our finding that $b d n f^{-1-}$ mice can respond to a hypercapnic stimulus indicates that the deficit in ventilatory control produced by loss of BDNF may be specific to the afferent pathway-mediating hypoxic ventilatory drive, although further studies are necessary to rule out other possible loci. It is unlikely that loss of motor output to the respiratory musculature contributed to the depressed ventilation, because motor neurons in the brainstem and spinal cord are unaffected by the BDNF null mutation (Ernfors et al., 1994a; Jones et al., 1994; Conover et al., 1995; Liu et al., 1995). However, our studies do not rule out the possibility of more subtle changes in motor output to the respiratory muscles.

Interestingly, BDNF heterozygous animals did not differ significantly from wild-type controls with respect to the ventilatory parameters we measured, although the mean values we obtained for this genotype were nearly always intermediate between $b d n f^{+/+}$and $b d n f^{-/-}$animals (Tables 3A,B, 4). It is possible that a more sensitive measure of ventilatory drive, such as direct neural recordings of respiratory motor output, might define more clearly 
A. $+/+$ $-1-$

B. $-1-$
Normoxia
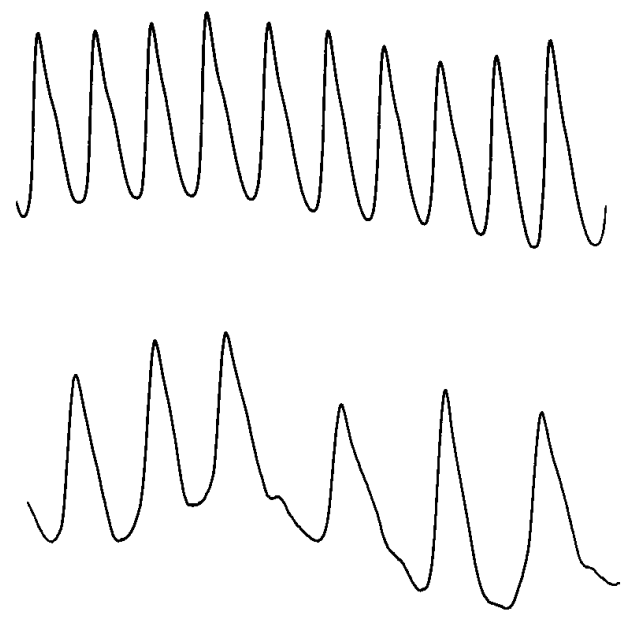

Normoxia



Hyperoxia


Hypercapnia

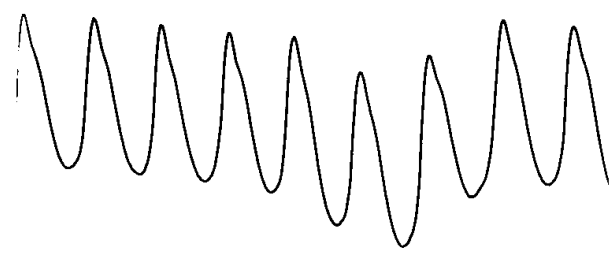

Figure 5. Ventilatory responses of individual neonatal mice to hyperoxia $(A)$ and hypercapnia $(B)$. Records show periods of quiet breathing without apneas. $A$, Hyperoxia depresses ventilation in $\mathrm{P} 2.5$ wild-type $(+/+)$ mice, primarily via a decrease in $V_{\mathrm{T}}$, but had no significant effect on either $V_{\mathrm{T}}$ or $f$ in knockout $(-/-)$ animals. $B, \mathrm{P} 3$ knockout mice were capable of increasing respiratory output above resting normoxic levels in response to $5 \% \mathrm{CO}_{2}$. Scale bars: vertical, $20 \mu$ l; horizontal, 2 sec.

the heterozygous phenotype. On the other hand, it is likely that the afferent populations that subserve reflex modulation of ventilation contain a substantial physiological "reserve," such that deficits are apparent only after neuronal losses below a threshold level, as in $b d n f^{-1-}$ mice. Moreover, the long-term physiological consequences of BDNF knockout clearly are linked to the severity of the deficit, because heterozygous animals are long-lived, whereas homozygotes die within 3 weeks of birth (Ernfors et al., 1994a; Jones et al., 1994; Conover et al., 1995; Liu et al., 1995). It is likely that a prolonged depression of breathing severely compromises oxygen-dependent metabolic processes during this period of rapid growth and contributes to the lethality of the $b d n f^{-/-}$ mutation.

In addition to defining a physiological role for BDNF in development of normal respiratory behavior, our data also may be important for understanding clinical syndromes of abnormal respiratory control in the neonatal period. For example, increased incidence of periodic breathing and apnea (Steinschneider, 1972; Guilleminault et al., 1979; Kelly et al., 1986), impaired regulation of alveolar ventilation (Shannon and Kelly, 1977), abnormal fluctuations in heart rate and respiratory patterns (Gordon et al., 1984; Schechtman et al., 1988, 1990, 1992), and abnormal development of vagal nerve fibers (Becker et al., 1993) have all been implicated as factors contributing to the Sudden Infant Death Syndrome. Impaired hypoxic ventilatory responsiveness may also contribute to some forms of congenital chronic hypoventilation syndrome (Marcus et al., 1991; Weese-Mayer et al., 1992; Ogawa et al., 1993). As shown in the present study, $b d n f^{-/-}$mice display many of these same deficits. Therefore, defining the relationship between growth factor dysfunction and autonomic pathophysiology in $b d n f^{-1-}$ mice as well as in other neurotrophin mutants may help to shed light on the molecular pathogenesis of these and related developmental disorders.

\section{REFERENCES}

Abercrombie M (1946) Estimation of nuclear populations from microtome sections. Anat Rec 94:239-247.

Barbacid M (1994) The Trk family of neurotrophin receptors. J Neurobiol 25:1386-1403. 
Bartlett D, Tenney SM (1970) Control of breathing in experimental anemia. Respir Physiol 10:384-395.

Becker LE, Zhang W, Pereyra PM (1993) Delayed maturation of the vagus nerve in Sudden Infant Death Syndrome. Acta Neuropathol (Berl) 86:617-622.

Benedetti M, Levi A, Chao MV (1993) Differential expression of nerve growth factor receptors leads to altered binding affinity and neurotrophin responsiveness. Proc Natl Acad Sci USA 90:7859-7863.

Bianchi LM, Conover JC, Fritzsch B, DeChiara TM, Lindsay RM, Yancopoulos GD (1996) Degeneration of vestibular neurons in late embryogenesis of both heterozygous and homozygous BDNF null mutant mice. Development (Camb), in press.

Buchman VL, Davies AM (1993) Different neurotrophins are expressed and act in a developmental sequence to promote the survival of embryonic sensory neurons. Development (Camb) 118:989-1001.

Chao MV (1994) The p75 neurotrophin receptor. J Neurobiol 25:1373-1385.

Chao MV, Hempstead BL (1995) p75 and Trk: a two-receptor system. Trends Neurosci 18:321-326.

Cherniack NS, Longobardo GS (1981) The chemical control of respiration. Ann Biomed Eng 9:395-407.

Clary DO, Reichardt LF (1994) An alternatively spliced form of the nerve growth factor receptor TrkA confers an enhanced response to neurotrophin-3. Proc Natl Acad Sci USA 91:11133-11137.

Cohen-Cory S, Fraser SE (1995) Effects of brain-derived neurotrophic factor on optic axon branching and remodelling in vivo. Nature 378:192-196.

Conover JC, Erickson JT, Katz DM, Bianchi LM, Poueymirou WT, McClain J, Pan L, Helgren M, Ip NY, Boland P, Friedman B, Wiegand S, Vejsada R, Kato AC, DeChiara TM, Yancopoulos GD (1995) Neuronal deficits, not involving motor neurons, in mice lacking BDNF and/or NT4. Nature 375:235-238.

Cordon-Cardo C, Tapley P, Jing SQ, Nanduri V, O'Rourke E, Lamballe F, Kovary K, Klein R, Jones KR, Reichardt LF, Barbacid M (1991) The Trk tyrosine protein kinase mediates the mitogenic properties of nerve growth factor and neurotrophin-3. Cell 66:173-183.

Crowley C, Spencer SD, Nishimura MC, Chen KS, Pitts-Meek S, Armanini MP, Ling LH, McMahon SB, Shelton DL, Levinson AD, Phillips HS (1994) Mice lacking nerve growth factor display perinatal loss of sensory and sympathetic neurons yet develop basal forebrain cholinergic neurons. Cell 76:1001-1011.

Curtis R, Adryan KM, Stark JL, Park JS, Compton DL, Weskamp G, Huber LJ, Chao MV, Jaenisch R, Lee K-F, Lindsay RM, DiStefano PS (1995) Differential role of the low-affinity neurotrophin receptor (p75) in retrograde axonal transport of the neurotrophins. Neuron 14:1201-1211.

Davies AM (1994) The role of neurotrophins in the developing nervous system. J Neurobiol 25:1334-1348.

Davies AM, Horton A, Burton LE, Schmelzer C, Vandlen R, Rosenthal A (1993) Neurotrophin-4/5 is a mammalian-specific survival factor for distinct populations of sensory neurons. J Neurosci 13:4961-4967.

Davies AM, Minichiello L, Klein R (1995) Developmental changes in NT3 signaling via TrkA and TrkB in embryonic neurons. EMBO J 14:4482-4489.

Dejours P (1962) Chemoreflexes in breathing. Physiol Rev 42:335-358.

Dobrowsky RT, Werner MH, Castellino AM, Chao MV, Hannun YA (1994) Activation of the sphingomyelin cycle through the low-affinity neurotrophin receptor. Science 265:1596-1599.

Ernfors P, Lee K-F, Jaenisch R (1994a) Mice lacking brain-derived neurotrophic factor develop with sensory deficits. Nature 368:147-150.

Ernfors P, Lee K-F, Kucera J, Jaenisch R (1994b) Lack of neurotrophin-3 leads to deficiencies in the peripheral nervous system and loss of limb proprioceptive afferents. Cell 77:503-512.

Ernfors P, Van De Water T, Loring J, Jaenisch R (1995) Complementary roles of BDNF and NT-3 in vestibular and auditory development. Neuron 14:1153-1164.

Fariñas I, Jones KR, Backus C, Wang X-Y, Reichardt LF (1994) Severe sensory and sympathetic deficits in mice lacking neurotrophin-3. Nature 369:658-661.

Finley JC, Polak J, Katz DM (1992) Transmitter diversity in carotid body afferent neurons: dopaminergic and peptidergic phenotypes. Neuroscience 51:973-987.

Garner AS, Menegay HJ, Boeshore KL, Xie X-Y, Voci JM, Johnson JE, Large TH (1996) Expression of TrkB receptor isoforms in the developing avian visual system. J Neurosci 16:1740-1752.
Gordon D, Cohen RJ, Kelly D, Akselrod S, Shannon DC (1984) Sudden Infant Death Syndrome: abnormalities in short-term fluctuations in heart rate and respiratory activity. Pediatr Res 18:921-926.

Guilleminault C, Ariagno RL, Forno LS, Nagel L, Baldwin R, Owen M (1979) Obstructive sleep apnea and near-miss for SIDS. I. Report of an infant with sudden death. Pediatrics 63:837-843.

Hantzopoulos PA, Suri C, Glass DJ, Goldfarb MP, Yancopoulos GD (1994) The low-affinity NGF receptor, p75, can collaborate with each of the Trks to potentiate functional responses to the neurotrophins. Neuron 13:187-201.

Hertzberg T, Hellström S, Lagercrantz H, Pequignot JM (1990) Development of the arterial chemoreflex and turnover of carotid body catecholamines in the newborn rat. J Physiol (Lond) 425:211-225.

Hertzberg T, Fan G, Finley JCW, Erickson JT, Katz DM (1994) BDNF supports mammalian chemoafferent neurons in vitro and following peripheral target removal in vivo. Dev Biol 166:801-811.

Heymans C, Bouckaert JJ (1930) Sinus carotidiens et réflexes respiratoires. C R Seances Soc Biol Fil 103:498-500.

Heymans JF, Heymans C (1927) Sur les modifications directes et sur la regulation réflexe de l'activité du centre respiratoire de la tête isolée du chien. Arch Int Pharmacodyn Ther 33:273-372.

Hofer MA (1984) Lethal respiratory disturbance in neonatal rats after arterial chemoreceptor denervation. Life Sci 34:489-496.

Hofer MA (1986) Role of carotid sinus and aortic nerves in respiratory control of infant rats. Am J Physiol 251:R811-R817.

Ibáñez CF, Ernfors P, Timmusk T, Ip NY, Areñas E, Yancopoulos GD, Persson H (1993) Neurotrophin-4 is a target-derived neurotrophic factor for neurons of the trigeminal ganglion. Development (Camb) 117:1345-1353.

Ip NY, Stitt TN, Tapley P, Klein R, Glass DJ, Fandl J, Greene LA, Barbacid M, Yancopoulos GD (1993) Similarities and differences in the way neurotrophins interact with the Trk receptors in neuronal and nonneuronal cells. Neuron 10:137-149.

Johnson EM, Taniuchi M, Clark HB, Springer JE, Koh S, Tayrien MW, Loy R (1987) Demonstration of the retrograde transport of nerve growth factor receptor in the peripheral and central nervous system. J Neurosci 7:923-929.

Jones KR, Fariñas I, Backus C, Reichardt LF (1994) Targeted disruption of the BDNF gene perturbs brain and sensory neuron development but not motor neuron development. Cell 76:989-999.

Katz DM, Black IB (1986) Expression and regulation of catecholaminergic traits in primary sensory neurons: relationship to target innervation in vivo. J Neurosci 6:983-989.

Katz DM, Markey KA, Goldstein M, Black IB (1983) Expression of catecholaminergic characteristics by primary sensory neurons in the normal adult rat in vivo. Proc Natl Acad Sci USA 80:3526-3530.

Kelly DH, Golub H, Carley D, Shannon DC (1986) Pneumograms in infants who subsequently died of Sudden Infant Death Syndrome. J Pediatr 109:249-254.

Klein R, Parada LF, Coulier F, Barbacid M (1989) TrkB, a novel tyrosine protein kinase receptor expressed during mouse neural development. EMBO J 8:3701-3709.

Klein R, Conway D, Parada LF, Barbacid M (1990) The TrkB tyrosine protein kinase gene codes for a second neurogenic receptor that lacks the catalytic kinase domain. Cell 61:647-656.

Klein R Nanduri V, Jing SA, Lamballe F, Tapley P, Bryant S, CordonCardo C, Jones KR, Reichardt LF, Barbacid M (1991) The TrkB tyrosine protein kinase is a receptor for brain-derived neurotrophic factor and neurotrophin-3. Cell 66:395-403.

Klein R, Smeyne RJ, Wurst W, Long LK, Auerbach BA, Joyner AL, Barbacid M (1993) Targeted disruption of the TrkB neurotrophin receptor gene results in nervous system lesions and neonatal death. Cell 75:113-122.

Kleinbaum DG, Kupper LL (1978) One-way analysis of variance. In: Applied regression analysis and other multivariable methods, pp 244288. Boston: Duxbury.

Levi-Montalcini R (1987) The nerve growth factor 35 years later. Science 237:1154-1162.

Lewin GR, Barde Y-A (1996) Physiology of the neurotrophins. Annu Rev Neurosci 19:289-317.

Liu X, Ernfors P, Wu H, Jaenisch R (1995) Sensory but not motor neuron deficits in mice lacking NT4 and BDNF. Nature 375:238-241.

Mains RE, Patterson PH (1973) Primary cultures of dissociated sympathetic neurons. I. Establishment of long-term growth in culture and studies of differentiated properties. J Cell Biol 59:329-345. 
Marcus CL, Bautista DB, Amihyia A, Davidson Ward SL, Keens TG (1991) hypercapnic arousal responses in children with congenital central hypoventilation syndrome. Pediatrics 88:993-998.

McAllister AK, Lo DC, Katz LC (1995) Neurotrophins regulate dendritic growth in developing visual cortex. Neuron 15:791-803.

Middlemas DS, Lindberg RA, Hunter T (1991) TrkB, a neural receptor protein tyrosine kinase: evidence for a full-length and two truncated receptors. Mol Cell Biol 11:143-153.

Mortola JP (1984) Breathing patterns in newborns. J Appl Physiol 56:1533-1540

Ogawa T, Kojo M, Fukushima N, Sonoda H, Goto K, Ishiwa S, Ishiguro M (1993) Cardiorespiratory control in an infant with Ondine's curse: a multivariate autoregressive modeling approach. J Auton Nerv Syst 42:41-52.

Riddle DR, Lo DC, Katz LC (1995) NT4-mediated rescue of lateral geniculate neurons from effects of monocular deprivation. Nature 378:189-191.

Rydén M, Murray-Rust J, Glass D, Ilag LL, Trupp M, Yancopoulos GD, McDonald NQ, Ibáñez CF (1995) Functional analysis of mutant neurotrophins deficient in low-affinity binding reveals a role for $\mathrm{p} 75^{\mathrm{LNGFR}}$ in NT-4 signaling. EMBO J 14:1979-1990.

Schechtman VL, Harper RM, Kluge KA, Wilson AJ, Hoffman HJ, Southall DP (1988) Cardiac and respiratory patterns in normal infants and victims of the Sudden Infant Death Syndrome. Sleep 11:413-424.

Schechtman VL, Harper RM, Kluge KA, Wilson AJ, Southall DP (1990) Correlations between cardiorespiratory measures in normal infants and victims of Sudden Infant Death Syndrome. Sleep 13:304-317.

Schechtman VL, Raetz SL, Harper RK, Garfinkel A, Wilson AJ, Southall DP, Harper RM (1992) Dynamic analysis of cardiac R-R intervals in normal infants and in infants who subsequently succumbed to the Sudden Infant Death Syndrome. Pediatr Res 31:606-612.
Schweitzer P, Pierrefiche O, Foutz AS, Denavit-Saubié M (1990) Effects of $N$-methyl-D-aspartate (NMDA) receptor blockade on breathing pattern in newborn cat. Brain Res Dev Brain Res 56:290-293.

Shannon DC, Kelly D (1977) Impaired regulation of alveolar ventilation and the Sudden Infant Death Syndrome. Science 197:367-368.

Snider WD (1994) Functions of the neurotrophins during nervous system development: what the knockouts are teaching us. Cell 77:627-638.

Soppet D, Escandon E, Maragos J, Middlemas DS, Reid SW, Blair J, Burton LE, Stanton BR, Kaplan DR, Hunter T, Nikoliks K Parada LF (1991) The neurotrophic factors brain-derived neurotrophic factor and neurotrophin-3 are ligands for the TrkB tyrosine kinase receptor. Cell 65:895-903.

Squinto SP, Stitt TN, Aldrich TH, Davis S, Bianco SM, Radziejewski C, Glass DJ, Masiakowski P, Furth ME, Valenzuela DM, DiStefano PS, Yancopoulos GD (1991) TrkB encodes a functional receptor for brainderived neurotrophic factor and neurotrophin-3 but not nerve growth factor. Cell 65:885-893.

Steinschneider A (1972) Prolonged apnea and the Sudden Infant Death Syndrome: clinical and laboratory observations. Pediatrics 50:646-654.

Timmusk T, Belluardo N, Metsis M, Persson H (1993) Widespread and developmentally regulated expression of neurotrophin- 4 mRNA in rat brain and peripheral tissues. Eur J Neurosci 5:605-613.

von Bartheld CS, Kinoshita Y, Prevette D, Yin Q-W, Oppenheim RW, Bothwell M (1994) Positive and negative effects of neurotrophins on the isthmo-optic nucleus in chick embryos. Neuron 12:639-654.

Weese-Mayer DE, Hunt CE, Brouillette RT (1992) Alveolar hypoventilation syndromes. In: Respiratory control disorders in infants and children (Beckerman RC, Brouillette RT, Hunt CE, eds), pp 231-241. Baltimore, MD: Williams and Wilkins. 